\section{Ecopreneurs and the Entrepreneurial Life Cycle Stages: A Multicase Study In Environmental Businesses}

\author{
Ananda Singh ${ }^{1}$ \\ Thálita Anny Estefanuto Orsiolli ${ }^{1}$ \\ Andréa Paula Segatto ${ }^{1}$ \\ ${ }^{1}$ Federal University of Paraná, Post-graduation Program \\ in Business Administration, Curitiba, Brazil
}

Received on

09/20/2018

Approved on

03/07/2019

Responsible editor:

Prof. Dr. João Maurício Gama

Boaventura

Evaluation process:

Double Blind Review

\begin{abstract}
Purpose - This study proposes to analyze the adaptation of ecopreneurs in each stage of the entrepreneurial life cycle.

Design/methodology/approach - Based on a qualitative approach of a descriptive nature, a multiple case study was conducted comprising four entrepreneurs from environmental enterprises. The data collection was performed through semi-structured interviews and documental analysis, and analyzed using the content analysis technique.
\end{abstract}

Findings - The results demonstrated that two stages demand common adaptations regardless of the context of the business, and the other one requires specific adjustments. Thus, a framework was proposed to present the adaptations ecopreneurs need to make during each stage of the entrepreneurial life cycle.

Originality/value - This study is expected to contribute to the literature regarding entrepreneurs and the stages of the entrepreneurial life cycle, as well as to ecopreneurs, specifically, by providing them with empirical data regarding possible adaptations they may face during each stage of the entrepreneurial life cycle.

Keywords - Ecopreneurship, Entrepreneurial life cycle, Opportunity.

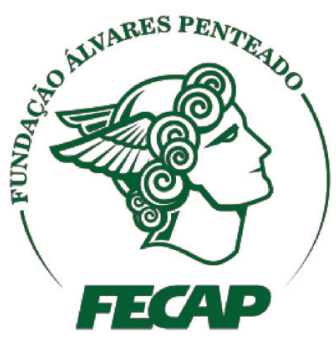

Review of Business Management

DOI: $10.7819 /$ rbgn.v21i3.4002 


\section{Introduction}

The concept of sustainable development published in the 'Our Common Future' (WCED, 1987) report has been consolidated as a political, economic, and social landmark (Ayuso \& Navarrete-Báez, 2017), mainly because it encourages changes in society in order to maintain the needs of future generations. Organizations began to reflect on the environmental and social impacts they caused, and to review their methods and production techniques, in order to minimize this damage.

The adoption of environmental and social practices by organizations led to opportunities for sustainable businesses (Boszczowski \& Teixeira, 2012). With the intensification of the search for solutions to these problems, new ventures began to emerge, stimulated by entrepreneurial action directed towards environmental and social practices, or even towards both combined (Cohen \& Winn, 2007; Schaltegger \& Wagner, 2011).

Ecopreneurship arises in this context, concerned with the minimization of environmental degradation and considering the use of natural resources in product manufacturing and in the services provided by enterprises. Innovative alternatives (Dean \& McMullen, 2007) enable the dismantling of traditional methods of production, and contribute to new techniques, structures, and patterns of consumption that can correspond to the needs and environmental demands (Schaltegger, 2002).

Market failures in the environmental focus can become a motivating factor for this type of entrepreneurship, by enabling business opportunities that generate economic and ecological benefits (Thompson, Kiefer, \& York, 2011). So, entrepreneurship, recognized as a driver of economies, a stimulator of competition between markets, and as a jobs creator (Schramm, 2010), has become an agent of change, while addressing environmental issues.

Thus, identifying the possibilities originating from the environment, as well as market failures (Dean \& McMullen, 2007), may enable environmental entrepreneurs - or 'ecopreneurs' - to strengthen and establish their businesses. In order to do so, entrepreneurs go through stages of the entrepreneurial life cycle, in which they have to adapt in order to develop and become properly established in the market.

Considering the context and reality of entrepreneurs in Brazil, this study proposes to analyze the adaptation of ecopreneurs in each stage of the entrepreneurial life cycle. To do so, a case study of four ecopreneurs was conducted.

Since ecopreneurship is still considered an emergent theme (Hall, Daneke, \& Lenox, 2010; Thompsom et al., 2011), studies are required in order to generate new discussions and deepen the understanding of the construct. Furthermore, the forms of adaptation identified in the results of this study can stimulate researchers when it comes to investigating the entrepreneurial life cycle in other contexts, or even suggest other research gaps. On the other hand, the practical contributions involve showing ecopreneurs the paths they can take in each stage of the life cycle and the possible adaptations needed in each of the stages of the life cycle.

\section{Literature review}

\section{I Ecopreneurship}

Entrepreneurship as is traditionally understood, regarding issues related to the generation of wealth and economic development (Easterly, 2002), has been the subject of discussions related to changes and opportunities in the market that require new types of entrepreneurship (Cohen \& Winn, 2007). Recognizing that "the environment undoubtedly influences entrepreneurship" (Bull \& Willard, 1993, p.191), it can be concluded that new opportunities are sought by entrepreneurs in order to solve a problem or meet a need, in addition to causing changes in business systems and developing new ideas (Schaper, 2002). It can be inferred that this phenomenon will also relate to the social context 
in which it is inserted, so as to respond to the pressures of society and the economic changes that have occurred.

Analyzing the environmental movements that arose in the 1960s, it is perceived that discussions were triggered in the economy and in the business environment (Croopper \& Oates, 1992), in order to address issues related primarily to environmental degradation and to the use of natural resources. Subsequent discussions and the establishment of the concept of sustainable development have intensified these discussions regarding impacts cause by enterprises (Du Pisane, 2006; Sachs, 2007). Such concerns, at the same time that they may represent limitations to certain corporate actions, can provide new business opportunities, as well as generating innovative alternatives (Dean \& McMullen, 2007). Thus, environmental and social issues can lead to sustainable business opportunities (Boszczowski \& Teixeira, 2012), as well as its practices being encouraged and/or incorporated by means of entrepreneurial action (Cohen \& Winn, 2007).

The interest in a sustainable business framework and the search for environmentally responsible business practices (Shaper, 2002) in order to provide solutions to environmental problems have stood out as growing conditions in the field of enterprises from the 1990s (Dixon \& Clifford, 2007). Moreover, with the intensification of the concerns about environmental degradation and the use of natural resources (Cohen $\&$ Winn, 2007; Dean \& McMullen), businesses and enterprises focused on the environmental dimension have been encouraged (Gast, Gundolf, \& Cesinger, 2017). A type of entrepreneurship has emerged to bring environmental issues into company strategies, this being called 'ecopreunership' (Pastakia, 1998; Schaltegger, 2002), environmental entrepreneurship (Thompson et al., 2011), green entrepreneurship (Berle, 1991), or environmental business (Holt, 2011).

It should be noted that environmental entrepreneurs are oriented towards developing practices that seek both economic and environmental growth, also addressing ethical and social issues. Ethical issues and concerns for future generations can also be motivating factors of environmental entrepreneurship as they help boost, by means of new technologies, environmental value creation (Anderson \& Leal, 2001).

Ecopreneurship may raise doubts concerning the pursuit of environmental solutions due to market failures or even due to opportunities that arise from the environment. This can be verified in a study carried out by Thompson et al. (2011) in which, when examining concepts and elements of the literature that differentiate between three types of entrepreneurship, key questions that may be essential to understand the emergence and establishment of environmental entrepreneurship are highlighted. The questions cover environmental opportunities, and why they are presented to some individuals. They also cover the role of these entrepreneurs in dealing with environmental degradation, as well as if this type of entrepreneurship contributes to reducing this degradation. Another line of questioning aims at understanding the process involved in this type of entrepreneurship, as well as its methods to identify and exploit opportunities. And the paper also seeks to understand the consequences for the environment and for society, when the environment is included in entrepreneurship, as an element in the market process.

The entrepreneurial life cycle presents a relevant means to better understand these questions, since it comprises opportunity identification (and why some individuals are more capable of identifying opportunities than others), as well as the role green enterprises play in environmental impacts (from the outcomes of green ventures and values generated in the exploitation phase), and the need for an intermediate phase (exploration) between identifying the opportunity and its exploitation. 


\subsection{The phases of the entrepreneurial life cycle}

\subsection{Opportunity identification}

Returning to the concept of sustainable entrepreneurship used in this paper, i.e., that "sustainable entrepreneurship involves the identification, exploration, and exploitation of new businesses that are, in economic development, the solution of an environmental or social problem" (Boszczowski \& Teixeira, 2012, p.143), the phases of the entrepreneurial life cycle can be observed in this concept. They are: opportunity identification, opportunity exploration, and opportunity exploitation.

As ecopreneurship is a subset of sustainable entrepreneurship, we can infer that these phases can be applied to it as well, since the life cycle of these environmental businesses involves the identification, exploration, and exploitation of opportunities that provide both economic and ecological benefits to society.

Some elements that promote the identification of opportunities, the first phase of the entrepreneurial life cycle, are: changes in economic, political, social, technological, and demographic variables; having prior information, as well as cognitive properties that allow the entrepreneur to evaluate the information held (Shane \& Venkataranam, 2000); changes in the information that the company has regarding available resources (Companys \& McMullen, 2007); new discoveries (Kirzner, 1973); new creations (Schumpeter, 1982); access to information that other competitors do not hold, whether technical or related to potential consumers and the market in which entrepreneurs may want to enter (Baron \& Shane, 2007; Shepherd \& DeTienne, 2005); and previous learning, life experiences, social relations established by the entrepreneur, education, and motivation (Costa, Machado, \& Vieira, 2007).

In addition to what these authors highlight, Shane (2000) points out that the entrepreneur must possess not only knowledge of the market, of its demands, or of existing needs, but also of the means that should be used to meet them.

Thus, it is observed that 'market failures', which consist of potential sources of opportunity identification (Dean \& McMullen, 2007), can be more easily identified by some individuals than by others. This occurs because some individuals are more likely to pay attention to these potential sources of opportunities, having what can be called 'an enterprise alert' level that is higher than that of other individuals. This alert is promoted by the combination of personality traits, prior knowledge, experiences, and participation in social networks that facilitate access and knowledge regarding the market that these individuals wish to penetrate, as well as the techniques and knowledge necessary to start the business they desire (Ardichvili, Cardozo, \& Ray, 2003).

\subsubsection{Opportunity exploration}

Even if the opportunity is identified, some time may elapse between this phase and the exploitation of the opportunity itself. This is so because, for the opportunity identified to be feasible, i.e., in order for the product or service the entrepreneur wants to offer to be effectively introduced in the market, adjustments in the product/service must be made, in order to increase its commercial viability. This gap in time between the moment of identifying the opportunity and its exploitation consists in the phase of the entrepreneurial life cycle that is called 'opportunity exploration'.

This phase exists because products and services identified as potential market opportunities may take time to be developed and deemed suitable for inclusion in the market (Degen, 1989), in such a way that they are commercially viable and 'ready' to be marketed.

For the author, products that are associated with technological and social developments, for example, often require this period of time between the identification of the opportunity and 
product/service's placement in the market. This intermediate period can even comprise decades.

Since "the recognition of opportunity involves the recognition that ideas are not only new and potentially useful, but also have the potential to generate economic value" (Baron \& Shane, 2007, p.61), planning and exploring the alternative ways to create such value must also be considered in the entrepreneur's actions.

However, developing the opportunity identified to make it commercially viable is not a simple task, as it may require previous knowledge to facilitate the adaptation of products or services to the market. Also, besides technical knowledge, previous experiences with business management are important to ensure that this adaptation will result in the success of the product or service identified as a market opportunity (Shane, 2003).

\subsubsection{Opportunity exploitation}

After they are identified and explored, environmental entrepreneurial opportunities should be exploited in order to create environmental value from the outcomes of the green business in question. To do so, "the opportunity exploitation process involves the development and enactment of strategic plans" (Hmieleski \& Baron, 2008, p.286).

However, these plans should be aligned to new legislation and changes in the market, so that the entrepreneurial opportunity comprises these demands and modifications, even after the venture is created.

Thus, opportunity exploitation can be considered a dynamic and continuous process, since it consists of adjusting the venture's strategic plans to the needs of the market and to the current legislation, at the same time as contributing to value creation from the outcomes of the enterprise (Costa et al., 2007). When it comes to environmental enterprises, these outcomes consist of solutions to an environmental problem identified as an entrepreneurial opportunity that can generate not only economic but also 'green' value (Thompson et al., 2011).

\section{Methodological procedures}

Using a qualitative approach (Merriam, 2009), this study seeks to understand how individuals must adapt during the stages of the entrepreneurial life cycle, based on the participants' interpretation of reality. Moreover, this article is descriptive in nature, since the researchers did not interfere with the facts, as they only registered, analyzed, classified, and interpreted them (Raupp \& Beuren, 2003).

This research uses a multiple case study, since this strategy has been shown to be adequate for exploring complex relationships involving the phenomenon investigated (the adaptations of entrepreneurs during the entrepreneurial life cycle stages), and it is based on the interpretation of the participants in the research (Yin, 2015). The use of this research strategy is justified because, although the literature features several studies in this area (Hall et al., 2010; Thompsom et al., 2011), it is still possible to investigate factors and questions regarding ecopreneurship and ecopreneurs' actions in more depth (Gast et al., 2017).

The criteria used to select the entrepreneurs that participated in this research were the following: (i) entrepreneurs of small enterprises; (ii) entrepreneurs that have gone through all three phases of the entrepreneurial life cycle; and (iii) entrepreneurs aiming towards generating not only economic values, but also green ones, as outcomes of their ventures.

Thus, four 'green' enterprises in Brazil were selected by theoretical sampling (Eisenhardt, 1989), considering their characteristics in relation to the values they believe in and seek to disseminate, the products and/or services that they develop, as well as the processes and production methods and management they use. Two of the enterprises manufacture and market sustainable clothing products, and the remaining two offer sustainable and eco-efficient services.

The data collection was performed through documental analysis, using information available on the institutional websites of the enterprises 
selected and semi-structured interviews with one of the owners of each enterprise chosen for this study. Two interviews were carried out with each entrepreneur (totaling eight interviews). The interviews were held from October 2017 to January 2018. After the data collection, we sought to analyze them using the content analysis technique, as proposed by Bardin (2010).

All categories were defined à priori, consisting of each stage of the entrepreneurial life cycle, that is, opportunity identification, opportunity exploration, and opportunity exploitation.

The data triangulation contributed to ensuring the internal construct's validity as well as the study's reliability, since multiple sources of data were used. The external validity of the study was based in the replication logic, since the results obtained are expected to be consistent with those of similar studies carried out, regarding the phenomenon studied here.

\section{Presentation and analysis of cases}

\section{I Presentation of the ecopreneurs and their ventures}

In order not to disclose the identity of the ecopreneurs and the ventures analyzed in this study, we chose to use codes A, B, C, and D for each venture and ecopreneur. The ecopreneurs studied, as well as their enterprises, are presented as follows:

Entrepreneur A: the entrepreneur is the only owner of the company she created in 2014 and is located in the south region of Brazil. The entrepreneur's age ranges between 26 and 35 years old, and she graduated in 'Design' and in 'Fashion and Design'. Her enterprise's main products are clothing items made using the upcycling technique, which is a technique in which clothing leftovers are used to create new pieces, and consequently, reduce the amount of clothing with no usage discarded in the environment. Sporadically, when the volume of demand is higher than usual, the owner hires two more individuals to help her produce her clothing items. The idea of creating Enterprise A came about when the entrepreneur got to know the upcycling technique and that it was not widely used in Brazil. This was an opportunity identified by the ecopreneur, since it involved an issue that was becoming a market tendency in the fashion industry: sustainability and material reuse.

Entrepreneur B: the entrepreneur is one of two owners of Enterprise B, created in 2016 and located in the southeast of Brazil. The entrepreneur's age ranges between 26 and 35 years old as well and he graduated in Information System. The main service provided by Enterprise $\mathrm{B}$ consists of collecting and disposing of electronic waste. Entrepreneur B created this company because he identified that there was no one providing this kind of service in his region. The ecopreneur observed that there was a huge amount of electronic waste; however there were no enterprises that provided services regarding its correct disposal. The environmental impacts of the enterprise are positive, since the services provided contribute to the correct disposal of electronic material.

Entrepreneur C: the entrepreneur is one of the three owners of Enterprise C, which was created in 2012, and is located in the south of Brazil. The entrepreneur's age ranges between 26 and 35 years old as well and she graduated in Design. The enterprise's main products are shoes made from raw materials (leather and fabric) that are no longer used by inactive industries or individuals who want to donate these raw materials. The enterprise was created because one of the owners' fathers had previously worked as a shoemaker and the ecopreneurs learned all about the industrial process of shoemaking from him. Combined with the know-how they developed by learning from one of the owners' fathers, the will to own an enterprise that comprised sustainable practices was a motivating element for starting the venture. The impacts on the environment promoted by the outcomes of Enterprise B are positive, since materials that would be disposed of are reused to make new products. 
Entrepreneur D: the entrepreneur is one of the two owners of Enterprise D, which was created in 2010, and is located in the southeast of Brazil. The entrepreneur's age ranges between 36 and 45 years old, and he graduated in Publicity and has an MBA in Business Management. The enterprise's main service is a sustainable industrialized construction system (Light Framing). Thus, Enterprise D operates in an industry involving sustainable architectonical projects. The venture came about with the idea of using the lean construction system. The environmental impact of the outcomes of the enterprise are positive, since the construction system is based on the generation of smaller amounts of residuum (from 2 to $3 \%$ of all material used) and less water consumption.

\subsection{Analysis of the entrepreneurial life cycle phases}

\subsection{Opportunity identification stage}

From Entrepreneur A's interview, it can be observed that she identified a market opportunity by using a not so frequently used method in Brazil, the upcycling technique. The entrepreneur came to understand the technique by herself, researching it in more detail on internet websites. The upcycling technique consisted of a 'technical knowledge' that other competitors from Brazil did not have. Also, the ecopreneur pointed out that the ones who were succeeding in the fashion industry were those who were working with sustainability.

However, in order to make this identified opportunity become a reality, Entrepreneur A had to adapt, through searching on the internet for foreign enterprises that used the technique, in order to deepen her knowledge about upcycling, since the method was still not widely spread and used in Brazil.

From Entrepreneur C's interview, it can be noted that the 'technical knowledge' she and her co-workers obtained was also the key element in contributing to the identification of the opportunity to create a new venture. The ecopreneur and the other owners learned from her colleague's father, who had previously worked as a shoemaker and who taught the ecopreneurs all he knew about the industrial process of shoemaking. This helped them develop the know-how they needed to start their venture.

However, Entrepreneur $\mathrm{C}$ and her coworkers had to adapt to conciliate their college schedules with the development of the new venture. The interviewee pointed out that they used their spare time from college to learn, from one of the co-workers' fathers, all about the process of making shoes.

Regarding the data collected from Entrepreneur B, it can be observed that the main source of opportunity identification, from the entrepreneur's perspective, was a market failure, combined with his previous experience working as an employee of a private company that was making him unsatisfied.

\footnotetext{
The venture aims to collect electronic waste, right? And it came about because I was a manager at 'AlgarSegurança' (a company in Brazil) and we always had the need to dispose of electronic equipment. And I didn't know what to do with it (the equipment) (Entrepreneur B, 2018).
}

Besides the market failures identified by Entrepreneur B (Dean \& McMullen, 2007) and his previous managerial experience in a private company (Ardichvili et al., 2003), another element can be observed that contributed to the ecopreneur identifying this opportunity: he had access to relevant information regarding a potential market for the correct disposal of electronic waste. The interviewee points out that he had access to this information by searching on the internet for companies that provided this kind of service. By doing so, Entrepreneur B became more familiar with the service of collecting and disposing of electronic material.

Regarding Entrepreneur D, he also identified a market opportunity in a service that was not offered in his region until then. 
The ecopreneur noted that the service of civil construction that used the Light Framing method was common in countries in Europe, the United States, and Japan, but was not used in Brazil.

Consequently, knowledge of the existence of a 'market trend' towards sustainability, as well as technical knowledge regarding the Light Framing system, were key elements in the identification of the use of this industrialized construction system as a market opportunity.

However, Entrepreneur D had to learn more about the new service that he wanted to offer, since he had no in-depth technical knowledge about the system.

To deepen his knowledge and abilities regarding the system, Entrepreneur D contacted some other entrepreneurs who were more familiar with the system, in order to better develop his know-how about the Light Framing method.

Thus, the empirical data from Entrepreneur $\mathrm{D}$, as well as the empirical data from both Entrepreneurs A and C, corroborate with Casson (2005), Costa et al., (2007); Sheperd and Detinne (2005), and Baron and Shane (2007), who point out that access to both technical and market tendencies' information is an element that contributes to entrepreneurial opportunity identification.

Also, from the data collected and analyzed, it can be noted that all entrepreneurs had to adapt - even though in different ways - during this phase of the entrepreneurial life cycle, in order to succeed in their new ventures.

Moreover, from the statements of interviewees $\mathrm{A}, \mathrm{B}$, and $\mathrm{D}$, it can be observed that all of them are more likely to pay attention to these potential sources of opportunity, having a higher 'business alert' level than others, which is consistent with Ardichvili et al. (2003).

This occurred because, like entrepreneurs A, B and D, other individuals (such as college mates of Entrepreneur A and other employees of the company in which Entrepreneur B worked) could also have identified market opportunities (such as the tendency to use sustainable products, in the case of Entrepreneur A) and these other individuals could also have identified the lack of companies that dispose of electronic material or use the Light Framing system (in the case of Entrepreneurs B and D, respectively). However, only these entrepreneurs envisioned these opportunities as being potential ones for the creation of new businesses, mainly due to their personality traits (Entrepreneur A has values geared towards the reuse of materials) and prior knowledge (Entrepreneur A knew about the upcycling technique, Entrepreneur $\mathrm{B}$ had knowledge of the lack of companies that disposed of electronic material in his area, and Entrepreneur D had knowledge of the sustainable construction system used in other countries).

Such empirical data corroborate with Ardichvili et al. (2003), who point out that these elements (personality traits and technical or market tendencies knowledge) are boosters of opportunity identification for new ventures.

\subsubsection{Opportunity exploration stage}

Even after identifying the opportunity to use the upcycling technique in clothing products, Entrepreneur A took care to test the market before properly commercializing her products. This trial period constituted the opportunity exploration stage of the entrepreneurial life cycle. Thus, before creating a venture of her own, to commercialize her own brand, Entrepreneur A accepted a proposal made by a college friend of hers suggesting that she could sell her products in his own second-hand store. In order to adapt to the situation, during this trial period, the ecopreneur had to use residuum and clothing items that had some quality issues, provided by her colleague, so that she could transform these pieces in new ones, using the upcycling technique. Since in this trial period the entrepreneur still did not have her own material to reuse nor her own resources to develop her products, this was the best option to test the potential market for her products (using her colleague's resources and his store to commercialize her clothing items). 
The ecopreneur pointed out that there was positive feedback regarding the demand and consumer acceptance of the products she sold in her friend's second-hand store, which compelled her to create her own store and brand.

However, Entrepreneur A mentioned that she did not have enough raw material to develop her products, so she had to adapt, by searching for this material in the 'fabric bank' of Curitiba (a city in the south of Brazil, in which the company is located) as an alternative source of fabrics, so that she could ensure her production would not stop due to lack of material.

The ecopreneur learned of the fabric bank of Curitiba on the internet and there she found fabrics with prints that interested her, leading to her becoming the largest consumer of the 'bank', and eventually she found a constant and reliable source of raw material in it to produce her clothing items.

Regarding Entrepreneur B, the main actions related to this stage of the entrepreneurial life cycle relate to the ecopreneur's learning. The entrepreneur used to be a manager of a department in the company in which he had previously worked, which helped him develop management knowledge. This is consistent with Shane (2003), who says that previous experiences in business management can contribute to this adaptation, resulting in the success of the product or service identified as a market opportunity. In addition, Entrepreneur B went to an association of amateur entrepreneurs, seeking to deepen his knowledge about entrepreneurship. This training allowed the entrepreneur to assess the viability of the business he wanted to create, as well as to prepare for managing it.

Entrepreneur $\mathrm{C}$ also had to go through an intermediate phase before properly exploiting the opportunity identified. The ecopreneur and her co-workers learned the industrial process of shoemaking for about a year, with the help of the co-worker's father. Also, similarly to what Entrepreneur A did, Entrepreneur C and her colleagues wanted to test the market in order to see if the shoes they wanted to commercialize had market potential. To do so, they would sell one pair of shoes to a friend and use the profit to produce more shoes. Then they would make another pair and sell it to another friend. This was how Entrepreneur $\mathrm{C}$ and her co-workers tested the market to see it there would be demand for the products they were making.

Similarly to what happened in Entrepreneur A's market testing, the feedback regarding consumer acceptance of the products Entrepreneur C offered was positive. This was the spark that made them decide to start their own brand properly.

However, Entrepreneur C points out that they had to adapt to the financial restrictions they had, in order to find a place to produce and sell their products as well as to find constant sources of the raw material they needed to produce the shoes. As stated by him:

During the first two years, we stayed in a place that our co-worker's father built, next to his house. We set up our 'industry' there. (Entrepreneur C, 2018).

For about a year we worked like this [...] buying raw material, developing the shoes, and all of a sudden we began to get raw material for free. [...] We took these leftovers and started to use them in our products. This was how the idea came about, as a possibility to save money buying cheaper raw material (leftovers) that would go to waste (Entrepreneur C, 2018).

Thus, Entrepreneur C and his colleagues began to see in leftovers a possible source of raw material to manufacture their products. Hence, it should be noted that this period was important for the entrepreneurs to identify possible sources of raw material that they could use in the shoemanufacturing process.

The main actions undertaken by Entrepreneur D at this stage concern the identification of how they could implement the 
idea identified in the previous stage, as well as the identification and adherence of potential consumers. To do so, the ecopreneur searched for clients, as well as identifying his clients' demands. Also, he made visits to architecture offices, to advertise their services and become known in the region. These actions were carried out over nine months (from January 2012 to October 2012), before the proper exploitation of the identified opportunity.

Since Entrepreneur D had had previous experiences with entrepreneurship and business management, in accordance with Shane (2003), such experiences were evidenced as important to adapt the services provided by Enterprise D to the real needs of its clients, helping the service provided to become commercially viable.

Thus, from the data collected, it can be observed that this trial period was necessary for the entrepreneurs to identify the market potential of the upcycling-made products (in the case of Entrepreneur A), to help the entrepreneur be able to create and manage his new enterprise by learning how to lead a new business (in the case of Entrepreneur B), for the entrepreneurs to learn the industrial process and to test the market (in the case of Entrepreneur C), to find constant sources of raw material (in the case of both Entrepreneurs A and C), and for seeking out consumers (in the case of Entrepreneur D). This empirical data corroborate with Degen (1989), since this phase took time to be developed, for all entrepreneurs analyzed here. The upcycling-made products were commercialized in the second-hand store for two years (from 2012 to 2014) before they were considered viable to be included in the market. Enterprise B was only created after the entrepreneur took entrepreneurship courses to enhance his knowledge regarding new venture creation and managerial practices; Entrepreneur $\mathrm{C}$ and her colleagues improved their knowledge about the industrial process for about a year and used a temporary place to produce the shoes; and Entrepreneur D took around nine months from the identification of the opportunity to its exploitation.
Thus, it can be seen that this intermediate phase was important to ensure that the products were commercially viable and ready to be introduced in the market, as well as agreeing with what Baron and Shane (2007) point out, that they had potential for economic value generation.

\subsubsection{Opportunity exploitation stage}

After exploring the opportunity, the next stage of the entrepreneurial life cycle consists of the opportunity exploitation. During this stage, the entrepreneurs must adjust the venture's strategic plans to the needs of the market and to the current legislation at the same time that the commercialized products contribute to value creation from the outcomes of the enterprise (Costa et al., 2007).

The main strategic actions of Entrepreneur A consisted of making a business plan that comprised, among other elements of the venture, the dissemination of its brand and product. In spite of having participated in a project in which a course was taught on business plan development, the entrepreneur realized that she would have to adapt the plan proposed by the course trainers to her own reality, since her production was different from the production process addressed in the course (serial production). So, Entrepreneur A states: "Then I decided to not follow that plan and to do my own (...), comprising unique and exclusive parts" (Entrepreneur A, 2018).

Thus, the entrepreneur adapted the strategic actions related to her potential consumers and to her production process, advertising the brand on the internet and the sustainable production process they use to produce their clothing lines. This form of dissemination is differentiated, since it is not carried out that way by direct competitors of the entrepreneur, also located in small stores. So, the entrepreneur believes that such actions contribute to creating sustainable value to the product she offers, and not only to the creation of purely economic value.

Since these actions were adapted to the needs of the potential consumers of the clothing 
lines produced by the entrepreneur, as well as contributing to the outcomes of the venture creating value (sustainable value is created since the fabric used to produce the clothing items is reused and economic value is generated from the sales), this evidence is aligned with Costa et al. (2007).

In the case of Entrepreneur B, the main strategic actions developed and implemented are related to the marketing of the service offered, to the development of logistics activities needed for handling and storage of the products collected, and to the development of partnerships with the recyclers in the area in which the enterprise is located.

The main difficulty highlighted by Entrepreneur B concerns the awareness of the potential consumers, when it comes to the proper disposal of electronic waste. Since this audience had no awareness of the proper disposal of these materials, the entrepreneur had to 'adjust' this public, helping them develop awareness, in order to be able to collect the electronic waste and later on discard it correctly.

This action, related to the commercial part, was necessary to ensure that the targeted consumers were prepared to use the services offered by Enterprise B. So, the entrepreneur had to adapt to the reality of the region in which he found himself, since in other regions and countries, this awareness may not be needed. This action is consistent with Costa et al. (2007), who claim that opportunity exploitation consists of a dynamic and continuous process, since it involves adjusting the venture's strategic plans to the real needs of the market.

In addition to awareness development, another adaptation of Entrepreneur B is related to logistics activities. Currently, in the area in which the venture is located, there is no proper disposal for the collected materials. This is done outside of the state, which means that the logistical planning carried out by the ecopreneur is complex, since it deals with such peculiarities
Also, the development of partnerships was another strategic action of Entrepreneur B, since he joined associations of entrepreneurs, with the intention of joining the recyclers of cooperatives in the area, in order to work together.

In the case of Entrepreneur C, the main strategic actions of the ecopreneurs were related to (i) developing a business plan, (ii) developing a design plan, (iii) implementing a product development plan, and (iv) developing a communication plan.

The entrepreneur also mentions that, to be able to carry out all this planning, prior knowledge acquired at college was essential.

The development of the design plan required some adjustments regarding the initial one. Entrepreneur $\mathrm{C}$ and the other co-owners of the venture decided to find some use for their own leftovers originating from the shoemaking process. They decided to add accessories and purses to their portfolio, in order to reuse the leftover leather from the shoemaking process that would go to waste otherwise.

Regarding the communication plan, to disclose the brand, Entrepreneur $\mathrm{C}$ mentions that they participated in events (for 2 years) every weekend, at fairs and at fashion weeks, in order to build a network of consumers. Such actions were essential for the cheap dissemination of the brand, since the entrepreneurs had no financial resources for major advertising and also due to the fact that the main consumers of the shoes sold by Enterprise $\mathrm{C}$ would go to these events. This helped ensure that both the brand and the sustainable production process used to manufacture the footwear sold by the entrepreneurs became known.

It is noteworthy that Entrepreneur C partners with Entrepreneur A, by providing leftovers from the shoemaking process, and they also get together from time to time to discuss and share new ideas regarding their portfolios and production process. Both entrepreneurs (A and C) also donate fabric and leather leftovers to other ecopreneurs, who use these raw materials in their production systems. 
Regarding Entrepreneur D, it is possible to observe that, during the exploitation phase, the main action that he had to perform was working with a management process to keep the operation sustainable. In addition, the ecopreneur also deals with issues related to the transportation of construction materials, since he does not have a specific location to store all the materials that are used in the constructions, and this ends up causing his transportation system to be very costly and takes a lot of time to be addressed. Also, Entrepreneur D seeks to work with an efficient system and use this feature as a differential to convince his potential customers to acquire his services, and not the competitors'. This required an adaptation from the ecopreneur, to the characteristics of the consumer market, which consists of a market that does not yet have the culture to see the long-term benefits of services, but instead only appreciates lower prices. Thus, the entrepreneur, facing the need to convince his potential consumers regarding the advantages of the services he provided, had to include such actions in his strategic and dissemination plan.

From the interviewees' statements, it is possible to observe that, despite the different natures, the empirical evidence provided by all the interviewees corroborates with Hmieleski and Baron (2008), since they illustrate the opportunity exploitation phase as comprising activities geared towards the execution of strategic actions and plans.

Even though in different ways, all the entrepreneurs analyzed here had to adapt to their realities and social contexts, whether through adapting their business plan, in order to contemplate the nature of their production process (Entrepreneur A), or through adapting their own potential consumers, in order to align the service offered to the consumers' actual demands (Entrepreneur B), or through the dissemination of products aimed at meeting specific needs of the consumers (Entrepreneur C), or even through convincing the potential consumers, on account of their cultural aspects (Entrepreneur D).

From the evidence obtained from the four entrepreneurs studied here, a framework is proposed that presents the main adaptations needed in each stage of the entrepreneurial life cycle (Figure 1). 


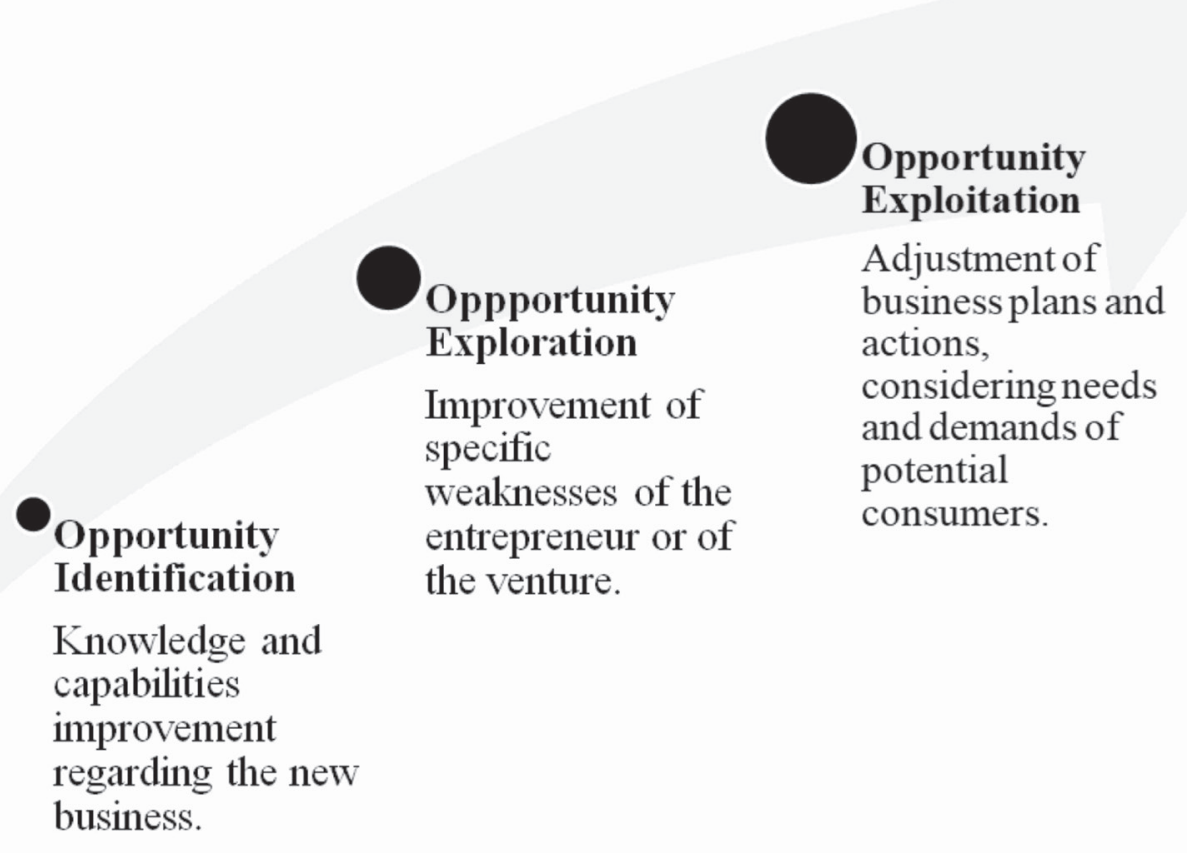

Figure 1 - Framework regarding the main adaptations needed from ecopreneurs during stages of the entrepreneurial life cycle.

Source: Elaborated by the authors (2018).

The framework proposed presents the adaptations the ecopreneurs needed to make during each stage of the entrepreneurial life cycle.

\section{Conclusions}

To analyze the ecopreneurs' adaptations in the life cycle stages, a case study of four ecopreneurs from Brazil was carried out. The evidence provides insights related to relevant adaptations in each of the stages of the entrepreneurial life cycle, in accordance with the cases investigated:

(i) Stage 1 - Opportunity Identification Stage - This stage's adaptations involve market opportunities and the main insights regarding the adaptations of all the ecopreneurs studied here are related to the search for knowledge and skills, regardless of their industry sector. Thus, to identify the opportunity, the entrepreneur must adapt and, as emphasized by Costa et al. (2007), use his/her education and motivation to perfect the idea and then exploit it.

(ii) Stage 2 - Opportunity Exploration Stage - These stage's adaptations are based on an analysis of the actual needs of the market and available resources, as well as an evaluation of the viability of the enterprise. The adjustments were similar for the entrepreneurs in the field of fashion and different for the other ecopreneurs analyzed. During this stage, each entrepreneur aimed to improve on their weak points, these being: resource limitations, knowledge, financial restrictions, and knowing their potential clients (Entrepreneurs A, B, C, and D, respectively). In this stage, the ecopreneurs seek to work on their weak points, in order to, as indicated by Degen (1989), make the products and services developed commercially viable and 'ready' to be marketed.

(iii) Stage 3 - Opportunity Exploitation Stage - In order to create both environmental 
and economic value, this adaptation arises from the identification of the needs and profiles of potential consumers. It also involves adjusting the business plan to the observed reality, or even changes in the portfolio of products resulting from new opportunities. In this case, despite some entrepreneurs having to also adapt in other aspects, all of them presented adaptations related to the actual demands of their consumers (through the installation of their stores in locations that are more accessible for their clients or through the alignment of supply and demand). As Hmieleski and Baron (2008) and Costa et al. (2007) claim, this phase aims at developing and adapting the strategic plans of the enterprise to the demands and requirements of the market.

Thus, the 'opportunity identification' stage and the 'opportunity exploitation' stage were common to all the entrepreneurs analyzed here, regardless of their business contexts. On the other hand, the actions and adaptations demanded in the second stage (opportunity exploration) were different for each entrepreneur, since they had to work on their specific weaknesses in order to develop and exploit their ventures so that the products and services they offer would be attractive to their potential consumers.

The framework proposed, which presents the adaptations the ecopreneurs need to make during each stage of the entrepreneurial life cycle, contributes theoretically to the domain of this study, providing the main elements of each stage of the cycle, in the context of ecopreneurship. In practical terms, this study can provide information to ecopreneurs, thus improving their knowledge regarding the paths they can take in the life cycle, and highlighting forms of adaptation that may be needed in each of the cycle's stages.

Even though this study achieved its purpose, one limitation regarding the number of cases analyzed can be pointed out. Since only four entrepreneurs were studied, it does not allow for generalization of the results obtained (Yin, 2014). Thus, for future research, we suggest analyzing more entrepreneurs, in order to validate the framework proposed and obtain enough evidence to enable generalization of the results obtained here. Also, we suggest that future research is conducted with the aim of studying clusters of enterprises, to verify if enterprises from similar clusters have the same adaptation needs in each stage of the entrepreneurial life cycle or if, depending on the context of the business, the adaptations differ.

This study is expected to contribute to the literature regarding entrepreneurs and the stages of the entrepreneurial life cycle, as well as to ecopreneurs, more specifically, by providing them with empirical data regarding possible adaptations they may face during each stage of the entrepreneurial life cycle.

\section{References}

Ayuso, S., \& Navarrete-Báez, F. E. (2017). How Does Entrepreneurial and International Orientation Influence SMEs' Commitment to Sustainable Development? Empirical Evidence from Spain and Mexico. Corporate Social Responsibility and Environmental Management, 25 (1), 80-94.

Anderson, T. L., \& Leal, D. R. (2001). Free market environmentalism. Stanford, CA: Hoover Institution Press.

Ardichvili, A., Cardozo, R., \& Ray, S. (2003). A theory of entrepreneurial opportunity identification and development. Journal of Business Venturing, 18(1), 105-123.

Bardin, L. (2010). Análise de conteúdo. Lisboa: Edições 70.

Baron, R. A. \& Shane, S. A (2007). Empreendedorismo: uma visão do processo. São Paulo: Thompson Learning.

Baumol, W. J. (2002) The Free-Market Innovation Machine: Analyzing the Capitalist Growth Miracle. Princeton: Princeton University Press. 
Berle G. (1991). The Green Entrepreneur: Business Opportunities That Can Save the Earth and Make You Money. Blue Ridge. Summit, PA: Liberty Hall Press.

Boszczowski, A. K. \& Teixeira, R. M. (2012). O empreendedorismo sustentável e o processo empreendedor: em busca de oportunidades de novos negócios como solução para problemas sociais e ambientais. Revista Economia e Gestão, 12(29), 141-168.

Bull, I., \& Willard, G. E. (1993). Towards a theory of entrepreneurship. Journal of business venturing, 8(3), 183-195.

Casson, M. (2005). Opportunity nexus: A review of Scott Shane: A general theory of individual entrepreneurship. Small business economies, 24(5), 423-430.

Cohen, B., Smith, B., \& Mitchell, R. (2008). Toward a sustainable conceptualization of dependent variables in entrepreneurship research. Business Strategy and the Environment, 17(2), 107-119.

Companys, Y. E., \& McMullen, J.S. (2007). Strategic Entrepreneurs at Work: The Nature, Discovery, and Exploitation of Entrepreneurial Opportunities. Small Business Economics, 28(4), 301-322.

Costa, C. R. F., Machado, H. V., \& Vieira, F. G. D. (2007). Comportamento empreendedor na exploração de oportunidades: história oral sobre o caso de uma indústria do setor alimentício. Desenvolvimento em questão, 5, 75-95.

Cropper, M. L., \& Oates, W. E. (1992). 'Environmental economics: a survey'. Journal of economic literature, 30, 675-740.

Dean, T., \& McMullen, J. S. (2007). 'Toward a theory of sustainable entrepreneurship: Reducing environmental degradation through entrepreneurial action'. Journal of Business Venturing, 22, 50-76.

Degen, R. (1989). O empreendedor: fundamentos de iniciativa empresarial. McGram-Hill. São Paulo.

Dixon, S., \& Clifford, A. (2007). Ecopreneurship - a new approach to managing the triple bottom line. Journal of Organizational Change Management, 20(3), 326-345.

Du Pisani, J. A. (2006). Sustainable developmenthistorical roots of the concept. Environmental Sciences, 3(2), 83-96.

Gast, J., Gundolf, K., \& Cesinger, B. (2017). Doing business in a green way: A systematic review of the ecological sustainability entrepreneurship literature and future research directions. Journal of Cleaner Production, 147, 44-56.

Hall, J. K., Daneke, G. A., \& Lenox, M. J. (2010). Sustainable development and entrepreneurship: Past contributions and future directions. Journal of Business Venturing, 25(5), 439-448.

Hmieleski, K. M., \& Baron, R. A. (2008). Regulatory focus and new venture performance: a study of entrepreneurial opportunity exploitation under conditions of risk versus uncertainty. Strategic Entrepreneurial Journal, 2(4), 285-299.

Holt, D. (2011). Where are they now? Tracking the longitudinal evolution of environmental businesses from the 1990s. Business Strategy and the Environment, 20(4), 238-250.

Kirzner, I. (1973). Competition and Entrepreneurship. Chicago, IL: Chicago Press.

Merriam, S. B. (2009). Qualitative Research: a guide to design and implementation. San Francisco: Jossey-Bass.

Pastakia, A. (1998). Grassroots ecopreneurs: change agents for a sustainable society. Journal of Organizational Change Management, 11(2), 157-173. 
Sachs, I. (2007). Ambiente e estilos de desenvolvimento. In Vieira, P. F. (Org.), Rumo à ecossocioeconomia: teoria e prática do desenvolvimento. São Paulo: Cortez.

Schaltegger, S. (2002). A framework for ecopreneurship. Greener Management International, 38, 45-58.

Schaper, M. (2002). The essence of ecopreneurship. Greener Management International, 38, 26-30.

Schumpeter, J. A. (1982). A teoria do desenvolvimento econômico. São Paulo: Abril Cultural, 1-169.

Shane, S. (2000). Prior knowledge and the discovery of entrepreneurial opportunities. Organization Science, 11(4), 448-469.

Shane, S. \& Venkataramam, S. (2000). The promise of entrepreneurship as a field of research. Academy of management review, 25(1), 271-226.

Shane, S. A. (2003). A general theory of entrepreneurship: The individual-opportunity nexus. Edward Elgar Publishing.
Shepherd, D. A., \& DeTienne, D. R. (2005). Prior knowledge, potential financial reward, and opportunity identification. Entrepreneurship theory and practice, 29(1), 91-112.

Thompson, N., Kiefer, K., \& York, J. G. (2011). Distinctions not dichotomies: Exploring social, sustainable, and environmental entrepreneurship. In Social and sustainable entrepreneurship Advances in Entrepreneurship, Firm Emergence and Growth (pp. 201-229). Bingley, UK: Emerald Group Publishing Limited.

Yin, R. K. (2014). Case Study Research: Design and Methods. 5th edition. Sage Publications, Thousand Oaks CA.

WCED (World Commission on Environment and Development). (1987). Our Common Future. Oxford University Press: Oxford, UK. 


\section{Appendix a - interview script}

Observation: All interviews should be recorded with the consent of the interviewees and later transcribed in order to facilitate the analysis of the evidence.

\section{Interviewee's profile}

1.1 In which course did you graduate?

1.2 Into which interval does your age fit?

\section{Basic information on the enterprise}

2.1 When and how did the venture start?

2.2 How many employees work in the venture?

2.3 Please, briefly describe how the venture came about and what were the main motivations for it?

\section{Entrepreneur's and venture's development}

3.1 Why did you choose to start a sustainable enterprise instead of a 'traditional' one?

3.2 Did you make any kind of business plan before creating the enterprise properly?

3.3 How did you learn to be an entrepreneur? Did you have any previous knowledge regarding entrepreneurship or enterprise management?

3.4 What were the main adaptations you had to make during the identification of the opportunity? 3.5 What were the main adaptations you had to make during the exploration of the opportunity? 3.6 What were the main adaptations you had to make during the exploitation of the opportunity 
Supporting Agencies: Coordenação de Aperfeiçoamento de Pessoal de Nível Superior (CAPES)

\section{Authors:}

1. Ananda Singh, Master in Business Administration, Federal University of Uberlandia, Uberlandia, Brazil. Email: a.singh@uol.com.br

ORCID

(D)0000-0003-4919-5649

2. Thálita Anny Estefanuto Orsiolli, Doctor in Business Administration, Federal University of Paraná, Curitiba, Brazil. Email: thalitanny@gmail.com

ORCID

(iD0000-0003-1796-3201

3. Andréa Paula Segatto, Doctor in Business Administration, University of São Paulo, São Paulo, Brazil. E-mail: andreapsegatto@gmail.com

ORCID

(iD 0000-0002-8903-9256

\section{Contribution of each author}

\begin{tabular}{lccc}
\hline Contribution & $\begin{array}{c}\text { Ananda } \\
\text { Singh }\end{array}$ & $\begin{array}{c}\text { Thálita } \\
\text { Orsiolli }\end{array}$ & $\begin{array}{c}\text { Andréa Paula } \\
\text { Segatto }\end{array}$ \\
\hline 1. Definition of research problem & $\sqrt{ }$ & & \\
2. Development of hypotheses or research questions (empirical studies) & $\sqrt{ }$ & $\sqrt{ }$ & \\
3. Development of theoretical propositions (theoretical Work) & & $\sqrt{ }$ & $\sqrt{ }$ \\
4. Theoretical foundation/ Literature review & $\sqrt{ }$ & $\sqrt{ }$ \\
5. Definition of methodological procedures & $\sqrt{ }$ & & \\
6. Data collection & & & \\
7. Statistical analysis & $\sqrt{ }$ & $\sqrt{ }$ \\
8. Analysis and interpretation of data & $\sqrt{ }$ & $\sqrt{ }$ & $\sqrt{ }$ \\
9. Critical revision of the manuscript & $\sqrt{ }$ & $\sqrt{ }$ \\
10. Manuscript Writing & & & \\
11. Other (please specify which) & & & \\
\hline
\end{tabular}

